\title{
China's Special Economic Zones, Hainan Province New Free Trade Zone: Review of Policies that Minimize the Regional Gap
}

\author{
Khalid Usman \\ School of Management, Foshan Polytechnic, Foshan City, P.R.China isakhelve@yahoo.com
}

\begin{abstract}
This research article begins with the illustration of China's special economic zone and regional inequity. We concluded that the decision to make Hainan free trade zone is one of the concrete step for the country to strengthen international trade and investment. However, shorten the negative list of foreign investment, can help to facilitate and attract the overseas investment. Until the attempt of special regional policies, the catching up and transformation did succeed in achieving the purpose of increase the development of the special economic zones, for this reason the coastal area advantages disproportionately. The Western Development policy that made better prosperous environment for foreign capitals in the western provinces did not show substantial absolute impact on encourages the growth and development in this region so far. The solution to this growing problem is to increase more special economic zones in China with regard to captivate foreign direct investment and stimulate the economy.
\end{abstract}

Keywords: -Free Trade Zones, Hainan Province, Special economic zones (SEZs), China, Regional disparity, FTZ Negative List, Regional economic policy.

\section{Introduction}

\subsection{Special Economic Zones (SEZ's)}

"Special economic zones (SEZs)" have undergone great changes. The word "SEZ" signify a huge variety of areas/zones, for instance, free trade zones (FTZ), the export-processing zones (EPZ), the industrial parks (IP), the economic and technology development zones (ETDZ), the high technology zones (HTZ), science and technology innovation parks ,etc. The basic ideology of special economic zones considers various particular features: (i) it's a geologically finite region, generally physically protected; (ii) it is the only administration or organization; (iii) within the zone, it presents a few points of interest for financiers physically; (iv) it has a distinct traditional region and efficient process (FIAS 2008).

Furthermore, a special economic zone usually functions under popularly in the country under the liberal economic laws. Generally, SEZs represent two primary sorts of benefits, which are partially entitled to SEZs reputation: "static" financial benefits which includes talent generation and talent upgrading, export development, overseas exchange income; and additional "vibrant" 
financial advantages along with upgrading expertise, transformation and improvement in technology, development of local firm's production (Zeng, 2010). The purpose of special economic zones are normally to accomplishing subsequent four strategic goals (Madani, 1999; Cling et al., 2001; FIAS, 2008; Zeng, 2010; Farole \& Akinci, 2011; Fuller \& Romer, 2012): (1) to attract overseas investment; (2) massively reduce un-employment; (3) supporting comprehensive strategy of economic reforms; and (4) building new experimental labs to implement fresh policies and procedures. Experts consider that special economic zones will be able to accomplish trade development in a more powerful and efficient way. Specifically, investment in special economic zones will : (i) offer bundle of public services in a geologically focused region; (ii) develop the restricted government financing potency or improve the government budget for infrastructure; (iii) assist the development of specific industry cluster; and (iv) motivate urban development facilitating contributory living standards for staff and for other science and technology workers., Hence, the special economic zones will be contributing of jobs designing and generation of income, moreover possibly, environment protection and economy environmentally-friendly cities and green growth deployment (Lin and Wang, 2014).

The scientific research illustrates that a lot of special economic zones have been able to exports promotion, FDI, jobs creating, and express the effect of cost-benefit positively (Warr, 1989; Chen, 1993; Jayantha kumaran, 2003; Gonzalez Monge, et al. 2005; Zeng, 2010; Romer \& Fuller, 2012). Nevertheless, numerous researchers see these zones as the 2 nd or may be $3^{\text {rd }}$ top alternative for growth, whose accomplishment is restricted to particular situation in a constrained time prospect Hamada 1974; Madani, 1999), and several other interests that may additionally emerge as "territory" (Kaplinsky, 1993).

Initially, the new industrial zone was entrenched in Shannon town, Republic of Ireland in 1959. Following 1970s, the SEZ- initially started in the region of Latin America and East Asia, generally with the kind of export processing zones (EPZs), build to appeal overseas finance and to promote exports (Farole, 2011). The export processing zones are usually in factory, with strict controls of custom and the products (usually more than $80 \%$ ) made within these zones should be exported to other foreign countries. This model of export processing zones was eminent in several states, including the Korea; Mauritius, Dominican Republic; Taiwan, Vietnam; China; and Bangladesh. In accordance to the International Labour Organization (ILO), few new trade zones have been established since and by 1986, there have been one hundred seventy six zones in forty seven states; and by 2015 it has been approximate that there have been more than four thousand three hundred zones more than one hundred thirty countries (The Economist, 2015). The SEZs play a vital role in new technologies transforming to China and the implementation of contemporary managerial practices (Zeng,2010).

\subsection{An Outline of Chinese Special Economic Zone Programs}

After the decade's central planned economy, in 1978, the Chinese government approved the openup policy and it determined that opening up in Guangdong province and Fujian provinces in the outside world and utilizes special policies and measures in July, 1979. However, Zhuhai, Shantou, Guangdong and Shenzhen were determined as special economic zones in August 1980 and after that, Fujian province and Xiamen were declared the special economic zones of China in October, 1980. Four special economic zones were rather similar because all zones covered huge area and can achieve the broad base purposes such as economic growth, FDI and global trade privileges.

The huge growth rate was measured in China because of an aggregation of favourable policy, strategies and the correct choices for the production factors in the special economic zones. From 1980 to 1984, the national annual average growth rate of GDP was $(10 \%)$, the annual rate of Shenzhen grew (58\%), however the other special economic zones such as Shantou (9\%), Zhuhai 
(32\%), and Xiamen (13\%). Moreover, in 1986, Shenzhen was already been developed in factors of production (Yeung, et al., 2009). Fourteen economic trade development zones (ETDZ) were already been build in different coastal areas from 1984 to 1988, however, within the next years more zones were established by Chinese government in other cities such as Min Delta in Fujian, Yangtze River Delta, and also the Pearl River Delta. Meanwhile, in 1988, Hainan was nominated as a $5^{\text {th }}$ complete special economic zone, accompanied by Shanghai Pudong new area and Tianjin Binhai new zone in 1989 and 2006. However, in addition to the SEZ pointed out above, there are numerous other varieties of special economic zones namely high-technology industrial development zones (HIDZs), free trade zones (FTZs), and export-processing zones (EPZs).

\section{Hainan Province Free Trade}

By October 2017, approximately 18,000 companies have already been enrolled in the special free trade zone, doubling the figure in the four earlier zones when they combined in September 2013. International trade in these rose $16.2 \%$ during the first three quarter of 2017 , and gradually rose year by year to 150 billion US dollars. The special free trade zone was started to pursue smooth business enrollment. Enterprises can enroll and start their business in these zones within three working days (Xinhua, 2018). According to Ren, (2014), more three free trade zones were started in Guangdong province, Tianjin city, and Fujian Provinces in 2014. However, in August 2016, seven more branches of third bath went operational. As structural reforms have developed innovation-driven growth, these free trade zones attract the investors to contribute innovation policy, startup in manufacturing, investment and other business related sectors. However, in January 2017, the Chinese government took further step to captivate international financing through trouble-free access and a greater business atmosphere. Overseas enterprises have already been facing limited restrictions in the field if services sector, mining and manufacturing sectors. The free trade zones trials build a model for economic transformation and opening up nationwide" (Xinhua, 2018). "The efforts to establish an international free trade zone in the South China Island have been resolved the strengthen globalization and to defend multilateralism."

A top expert and a former vice-minister of commerce of the China, Mr.Wei Jianguo said, Hainan free trade zone is a concrete step to promote international investment as well international trade, and more hard work is needed to make this success. However, other experts illustrate that this project includes a new phase of Chinese economy reform and opening up because the island is likely to compete with other international ports such as Hong Kong and Singapore (Telegraph, 2018). Under the plans of central authorities declared on 14 April 2018, the tropical resort island of the country will transform into a free trade port and free international trade by 2025 .

Wei Jianguo alleged economies are being encouraged around the world help to improve the Hainan development. Thus, Hainan can perform a greater role in global economy growth. This project offers a model for the development of South Asian countries and also promotes the development of mainland and coastal areas. This effort emphasizes China's solution to strengthen internationalization and to protect multilateralism. Hainan free trade zone competes effectively to maintain the country's growing trade protection, the speed of global trade and to make the international investment easier. "Moreover he said that in support of the development of Hainan, further policies may be implemented in the future. That consists of broader opening-up policies and wider transformation measures in areas such as law formulation of law, guidelines for investment, and systems of finance and visa policy. However, some other Experts assumed that there is much to expect from Hainan due to the fact a free-trade port represents the highest level of opening by global standards and mean that most goods and services are very low or even zero tariffs (China Daily, 2018). 
According to Mr. Wei, the Hainan FTZ will work as a new way for China to strengthen regional economic integration and to further support the development of the global economy. It's a Chinese plan that is applies to international growth. Economies are being encouraged around the world to try to help improve the development of Hainan. In comparison to Hong Kong and Singapore, Hainan will use its resources to develop and a long-lasting benefit with the rapid development of China. According to an economist of the China Centre for International Economic Exchanges, Mr. Xu Hongcai, the project will promote the international status of island and convert it into an economic centre that can attract foreign investment and talent. Hainan development has strategic significance for the development of overall country, and promotes new planning policy which is necessary for the next round of reform and opening up."It's a newest version of the country's reform and setting up, and some of the measures are better than earlier policies" (China Daily, 2018; Telegraph, 2018).

A deputy director of the China Institute for Reform and Development, Mr. Xia Feng, said "The tropical islands such as Hainan, their growth and development is depend on the setting up policies as compare to inland areas. A plenty of complete procedures are required to assure the open stream of resources like capital and skills." The president of the China Institute for Reform and Development, Chi Fulin elaborate that Hainan's assets include its large area and huge local resources that cannot compete with China's other free-trade zones: "In Comparison to Hong Kong and Singapore, Hainan will use to develop its own resources. I suppose it's going to have a late-mover benefit with rapid development" (Telegraph, 2018).

According to Mr. Xie Xiangxiang, who is working in the School of Tourism of Hainan University as a associate professor said that there is a powerful starting point to transforming the entire island into a free trade zone, aimed at becoming a global tourism and consumption center. The biggest challenge facing the island is a lack of talent that the province has to enhance its education and training (Telegraph, 2018).

\section{Foreign investors with shortened FTZ negative list}

In the SPFTZ, a foreign investment project is not required to ratify the Government of China, unless it is enclosed in a negative list. The previous version of negative list was announced by the Shanghai municipal authorities, there were 190 items in 2013 and continuously decreased to 139 in 2014.The list has further reduced in 2015. However, the negative list will further decreased in this year, which limits overseas financing, in its free trade zones (FTZs). The spokesperson for the Ministry of Commerce (MOC) Mr Sun Jiwen, said China has decreased the restrictions in 2017 in the field of research and development, information and communication technology, mining, investment and manufacturing sectors etc. For instance, foreign financier can now design and manufacture civil helicopters with a maximum weight of three tones and above in the FTZs. Moreover, the ministry has additionally encouraged pellucidity of the negative list in helping to help overseas investment. China's free trade zones are an approach to analysis new policies, which include limited restrictions on investment, and liberalization rate or interest, in order to improve the economy in international ways. According to the 2016-2020 plan released by the State Council in January 2017, China will setup integrated and transparent market access policies and to develop the market access, the China will also promote reforms in the commercial registration system (Xinhua, 2017).

\section{Regional Difference}

There are regional differences in Chinese history (Kanbur \& Zhang, 2005). The Chinese region consists of provinces with analogous geographical locations, which have similar economies, topography, geography and Cultural Features. The disparity between China's regions has turned into significantly division of income and, to a certain level, the living standard between major 
agrarian areas and metropolitan areas (Qian \& Smyth, 2008). Nearly all of these metropolitan areas lie in the coastal/seaside areas of the country, though China's central and western regions are dominated by agriculture (Zhang \& Fan, 2004). If the disparity between central and coastal regions becomes too large, it may become an unstable factor in the Chinese economy (Zhao \& Tong, 2000).

In the mid of 20th century, China established a centrally planned economic framework. Yet, after 1970s, it began to shift to a free market-based economy. The decentralization of government resource was the initial and crucial measure of Chinese government in this regard (Lin \& Liu, 2000). Therefore, the least essential prospect of this decentralization was that it intervenes ahead of regional boundaries (Qian, 2000). As a result, the degree of decentralization in coastal areas has increased as compare to the central and western regions of the state. Due to the establishment of special economic zones (SEZs), this decentralization ultimately escort to the denationalization of resources. Special economic zones are a general term that depicts changes in traditional business districts (Zeng, 2010).

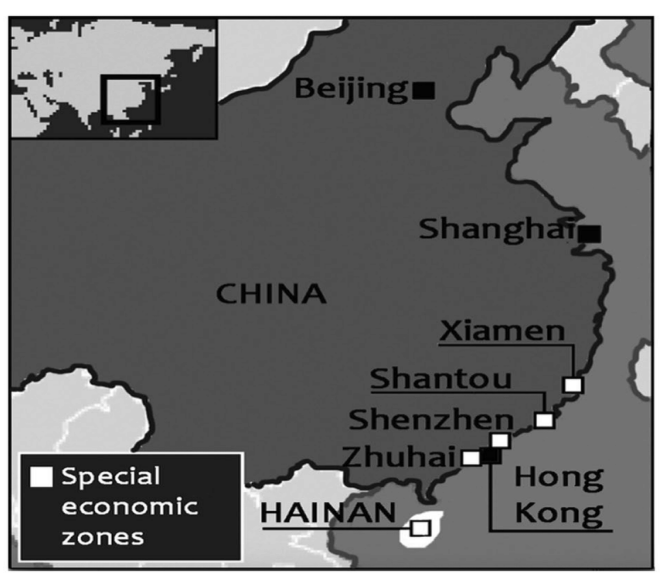

Figure 1 China's special economic zones (SEZ). Source: Yitao and Meng (2016)

There was a centrally planned economic system, through the independence of China in 1949 to 1979 that bucked up fast industrialization while maintaining a comparatively low dependence on international economic investment (Fujita \& Hu, 2001). After the development of the special economic zone, China has used the market and the centrally planned economy (Ge, 1999). There are five major special economic zones, with the addition of Hainan Province in 1985 (Yitao \& Meng, 2016).

The neoclassical growth models anticipate the general paradigm of economic divergence, where impoverished regions incline to approach with wealthier regions inside a state or territory (e.g., Carlino \& Mills, 1993; Yang, 2002). Although this paradigm has verified effective in Western Europe and the United States region (Barro \& Sala-i-Martin, 1995), but it does not more effective in China. The launching of special economic zones has enhanced the gap between regions. The top 10 provinces in 2000, with GDP per capita were mainly through the coastal areas of eastern China (Zhang \& Zou, 2012).

\subsection{Impact of SEZs on Regional inequity within China}

SEZs were the "catalysts" undertake revolution of the China's economy, from a centrally planned economy that integrated prospect from both a centrally planned economy and a free marketbased economy (Wei \& Ye, 2004). The purposes of special economic zones were to create a "spill- 
over effect", and the growth of economy in coastal areas will continuously stream to the central and west regions/territory (Litwack \& Qian, 1998).

Moreover, to stimulating the economy of China by captivating international investment, the special economic zones also assisted transformation the economy of China by operating foreign materials, remunerative trade, joint project, joint ventures and foreign capital-based companies (Nishitateno, 1983). This consecutively has entitled to grow China's economy and utilize foreign investment to further evolve and build special economic zones.

A greater economic impact has recorded in the region with multiple SEZs as compared the region with only one SEZ. In addition, the areas where the special economic zones were established previously produced greater positive economic benefits as compare to those were established later (Goldstein, 1998). The significant economic results of the SEZs on the state's economy have been the amount of income and income volume of individuals in the area (Wang, 2012). As more and more international companies spent money with in competitive resources and human resources in the area, more resources inclined to stream to the whole country. Unluckily, yet, the "spillover effect" from one areas to another has never been entirely appeared (Gross, 1988).

There are different elements that have led to shortage of spillovers within the regional disparities of China's provinces. In the initial four special economic zones, public and international companies were subsidized with pleasant tax benefits and tax including employment versatility. These zones were very prosperous and China has turn into the biggest beneficiary of FDI in underdeveloped nations (Zhang \& Zou, 2012). The inflow of these resources has led to divergent developments in infrastructure, technology and human capital in coastal provinces (Fleisher, Li, \& Zhao, 2010; Démurger, 2001).

On the other hand, the most important factors in the development of regional differences are Geographic location, government-owned enterprises (SEO) and natural resources (Nee, 1992; Zhang \& Zou, 2012). Large state owned enterprises (SEOs), were further accumulated in interior provinces, and they had well approach to the natural resources that promote output. In addition, China was unwilling to denationalize these enterprises and limit foreign direct investment in inland areas. In 1995, when industrial output dropped and large-scale SEO dismissals, policymakers turned to some basic public grants for some SEOs. Nevertheless, because the noncoastal provinces did not have as much right to foreign direct investment, the labor market was not as mature as the coastal areas, and many laid-off workers cannot be rehired, so the gap will only increase (Zhang \& Zou, 2012).

Finally, granting for networks of infrastructure also affects regional disparity (Démurger, 2001). Since decentralization, the local government revenue has been the main source of financing for the development of infrastructure, with more capitalization in infrastructure in zones with additional resources. There were less capitalization in developing the infrastructure of the connected zones and a "trickle down" effect in non-coastal areas. Conversely, development of infrastructure in rich regions promoted the localized network growth that can well allocate resources and execute them with the economy of state (Sahoo, Dash, \& Nataraj, 2010; Zhang \& Zou, 2012).

\subsection{Impact of Chinese policies on Regional inequity}

As we discussed before, China has tried to lockup the gap between the coastal, central and western regions of the country through the implementation of policies and strategies. Yet, financial decentralization and municipality bias policies have led to regional inequality.

Nevertheless, due to the failure of the region to evolve an industrial structure appertaining to its own unique comparative strengths, decentralization and foreign trade protection both produce 
local regional trade protection. Local trade protection can widen China's regional disparity (Qui, Li, \& Sun, 2003). In order to bring down and get rid of local protectionism, including the establishment of a Ministry of Domestic Trade, Chinese Central Government has made several efforts, with the main intention of ensure the circulation and distribution of goods throughout the country, and the mediation of inter-regional trade conflicts (Fleisher \& Yang, 2003; Young, 2000).

Of course, this has little effect on maritime areas that pursue in international trade and expand economies of scale. Moreover, decentralization is good for regions which has stronger economy, because these regions will generate more income. In addition, local budget control hinders the development of infrastructure (such as highways, telecommunications, and electricity), especially in connecting areas, as some infrastructure was more effective nationwide (Zhang \& Zou, 2012). Because of these several reasons and indications, financial decentralization actually changes regional disparities. Zhou and Zhang (2008) found that there is negative link amid decentralization and provincial growth of economy.

Chinese government modifying the urban polices because of the rapidly growing population in urban areas, these are big political and economic instability threat for the country. Because provinces with highest GDP likely to be more urbanized, such policies are conducive to intensification of inequality in coastal areas and regions (Chen, 2002; Fu, 2004; Zhang \& Zou, 2012).

The central government of China accepted that the regional gap has widen and invested in the domestic non-coastal economy to narrow the economically gap between regions. The Chinese government initiated to prioritize the inland areas, later the Asian financial crisis in 1997 (Ahmed \& Grewal, 2011). They comprehend that the economy needs to be diversified, not just depend on foreign direct investment. Therefore, Chinese government initiated to concentrate on the betterment of industrial centers in the western region (Fan, 1997). Then it established a development center in the northeast and started to prioritize the central region at the beginning of the 21st century.

Unluckily, engagement of Chinese government has hardly renounced this problem. The Chinese government has also carried out large-scale reforms of government-owned enterprises, resulting in a wide range of joblessness, and further role playing in the Northeast and the West to help the needs of the thriving coastal areas (Zheng, 2007).

The primary factors of the Western Development Strategy include the evolution of transportation networks, infrastructure, telecommunications systems and hydropower stations; policies to provide preferential treatment for energy, environmental regulation, mining, ecological protection, tourism and agricultural processing; betterment of public sector especially for those associated to education and public security; attracting foreign direct investment and reducing tax rates. Such policies are not as important as the liberalization of SEZs (Sun, 2013), which explains the regional disparities of economic growth of China.

The Western Development Strategy aims to improve the older industrial centers that were massively used through the command of Mao Zedong. Deng Xiaoping, who thrived Mao Zedong in heading the country, Deng Xiaoping adopted a policy of trickle down, while Mao adopted a policy of counter-polar (Harding, 2010). The counter-polar policy itself helps to encourage a statecontrolled economy and eventually utilizes resources in a very incompetent manner (Golley, 2007; Li \& Yang, 2005; Zhang, 1999). This is because the focus of the counter-polar policy is to concentrate national resources in a few underdeveloped regions and needed the government of China to "pick winners". Mao Zedong highlighted the production and resources of production of the central and western regions. Whereas Deng Xiaoping seize to power, he refused to adopt 
an counter-polar policy, but adopted a trickle down approach that would benefit geographical and economic advantages in coastal areas and the west (Chen, 1995).

The aim of the government is to totally necessitate regional disparity experienced by the West province. The western development policy has generated more prosperous circumstances for investment in the western region, but it has no obvious positive result on boosting the development of the western region. However, disparity were decreased by infrastructure investment, establishing economic relationship between the coastal regions as well as the West regions, and to increase the capacity of foreign direct investments (FDIs) amount in the West provinces (Sun, 2013; Zheng \& Kuroda, 2013) .

\subsection{Potential to resolve Regional inequity and expanding of Chinese special economic zones}

The number of researchers using various scientific approaches to predict the "regional inequalities in China". The applications of Quantitative approaches are better to understand the problem rather than using qualitative approaches. To present a time variation of China's regional inequality, Kanbur \& Zhan, (1999) and Wan, (2007), utilize the Theil-L inequality indexand generalized entropy (GE) class of inequality measures. The trends drawn from current investigation shows that there is a huge income difference between countryside and metropolitan region, and that regional inequality directly affects the size of the family, approach to government social services, and the accessibility of human resources in the manpower specific areas (Wan, 2007).

According to Shankar (2003), numerous studies elaborate that particular methods should be interpreted to decrease the regional disparities in China. However, these formation includes building a large network of social protection scheme that directly benefits to poor and lower income level employees, handling local level economics resources and develop infrastructure in less developed regions (Fan, Kanbur , \& Zhang, 2011). They help to captivate foreign direct investment and foreign companies that promote the economy and help raise living standards (Sharma, 2009).

It's better to implement the SEZ in the central or western region of China that will be the best way-out to reduce the regional disparities which is exist today. China has started to further stimulate the Chinese economy by establishing more special economic zones in Africa (Bräutigam \& Xiaoyang, 2011).

\section{Conclusion}

This paper analyses the special economic zones in China, and puts forward some solutions to solve the growing regional differences. In our this research article, international literature focused on and highlighting Hainan province free trade zone benefits, and proposing solutions to regional inequalities in China (e.g. Chen, 2010; Fleischer et al., 2010; D_Murger, 2001). However, we concluded that the plan to establish an international free zone in Hainan province will not only increase the growth of South China, but also promote the economic growth of Asia-Pacific region and all over the world. The free trade zone project has been introduced, due to the new level reforms and the opening of China economy, because the Hainan, Tropical Island has great advantage to engage with foreign port such as Hong Kong and Singapore. The decision to make Hainan free trade zone is one of the concrete step for the country to strengthen international trade and investment. However, shorten the negative list of foreign investment, can help to facilitate and attract the overseas investment. Hainan FTZ is a way to test new policies, which include rate of interest liberalization and limited restriction on investment, to better combine the economy with overseas practices. 
On the other had our research shows that China's growing regional disparity is a complex issue with many suggested solutions. The disparities between different regions were discussed. The impact of special economic zones on these areas has then addressed disparities and analyzed some trends from different other studies.

Until the attempt of special regional policies, the catching up and transformation did succeed in achieving the purpose of increasing the development of the special economic zones, for this reason the coastal area advantages disproportionately. The Western Development policy that made better prosperous environment for foreign capitals in the western provinces did not show substantial absolute impact on encouraging the growth and development in this region so far.

The solution to this growing problem is to increase more special economic zones in China with regard to captivate FDI and provoke the economy, consequently all regions in China begin to assemble and closure the economical gap. The poor regions are catching up with the rich ones, in such a way the disparity in the degree of living norms between the poor and the rich is consistently increasing.

However, we recommend that the rich regions help to narrow the gap between poor regions. In addition, more work is required to promote regional integration to reduce the regional disparities. More work and efforts are needed to be done to solve this trouble.

\section{References}

Ahmed, A., \& Grewal, B. (2011). Is China's western region development strategy on track? An assessment.Journal of Contemporary China,20, 161-181.

Barro, R. J., \& Sala-i-Martin, X. (1995). Economic growth, 1995. New York, NY: McGraw-Hill.

Bräutigam, D., \& Xiaoyang, T. (2011). African Shenzhen: China's special economic zones in Africa. The Journal of Modern African Studies,49(1), 27-54. Retrieved from http://www.jstor.org/stable/23018877

Carlino, G. A., \& Mills, L. O. (1993). Are US regional incomes converging: A time series analysis. Journal of Monetary Economics,32(2), 335-346.

Chen, C. (1995). The role of foreign direct investment in China's post-1978 economic development. World Development,23(4), 691-703.

Chen, A. (2002). Urbanization and disparities in China: Challenges of growth and development. China Economic Review,13(4), 407-411.

Chen, A. (2010). Reducing China's regional disparities: Is there a growth cost? China Economic Review,21(1), 2-13.

Chen, M., \& Zheng, Y. (2008). China's regional disparity and its policy responses. China and World Economy, 16(4), 16-32.

Chen, J., 1993. "Social Cost-Benefit Analysis of China's Shenzhen Special Economic Zone." Development Policy Review 11(3):261-71.

China Daily., 2018.Hainan plans good news for free trade. http://www.chinadaily.com.cn/a/201804/17/WS5ad55a98a3105cdcf6518bd5.html

China Organization., 2018. Hainan boosts medical tourism as new growth driver. http://www.china.org.cn/china/NPC CPPCC 2018/201803/07/content 50674782.htm 
Cling, J.P. and G. Letilly,. 2001. "Export Processing Zones: A Threatened Instrument for Global Economy Insertion?" DIAL/Unite de Recherche CIPRE Document de Travail DT/2001/17 (November).

Demurger, S. (2001). Infrastructure development and economic growth: An explanation for regional disparities in China? Journal of Comparative Economics,29(1), 95-117.

Fan, C. C. (1997). Uneven development and beyond: Regional development theory in post-Mao China. International Journal of Urban and Regional Research,21(4),620-639. doi:10.1111/14682427.00105

Fan, S., Kanbur, R., \& Zhang, X. (2011). China's regional disparities: Experience and policy. Review of Development Finance,1(1), 47-56.

Fleisher, B., \& Yang, D. (2003). China's labor market. Mimeo: Department of Economics, Ohio State University.

Fleisher, B., Li, H., \& Zhao, M. Q. (2010). Human capital, economic growth, and regional inequality in China. Journal of Development Economics,92(2), 215-231.

$\mathrm{Fu}, \mathrm{X}$. (2004). Limited linkages from growth engines and regional disparities in China. Journal of Comparative Economics,32(1), 148-164.

Fujita, M., \& Hu, D. (2001). Regional disparity in China 1985-1994: The effects of globalization and economic liberalization. The Annals of Regional Science,35(1), 3-37.

Farole, T. and G. Akinci (eds.)., 2011. Special Economic Zones: Progress, Emerging Challenges, and Future Directions. World Bank.

Farole, T. and G. Akinci (eds.)., 2011. Special Economic Zones: Progress, Emerging Challenges, and Future Directions. World Bank.

FIAS., 2008. Special Economic Zones: Performance, Lessons Learned, and Implications for Zone Development. Washington, DC: World Bank.

Fuller, B. and P. Romer., 2012. "Success and the City: How Chartered Cities Could Transform the DevelopingWorld?"A McDonald-Laurier Institute publication(April).

Ge, W. (1999). Special economic zones and the economic transition in China. Danvers, MA: World Scientific.

Goldstein, M. (1998). The Asian financial crisis: Causes, cures, and systemic implications. Washington D.C.: Institute for International Economics

Golley, J. (2007). China's western development strategy and nature vs. nurture. Journal of Chinese Economic and Business Studies,5(2), 115-129.

Gross, H. (1988). China's special economic zones. China Law Reporter,4, 23-40.

Harding, H. (2010). China's second revolution: Reform after Mao. Washington, D.C: Brookings Institution Press.

Ho, C. Y., \& Li, D. (2008). Rising regional inequality in China: Policy regimes and structural changes. Papers in Regional Science,87(2), 245-259.

Hamada, K., 1974. "An Economic Analysis of Duty-Free Zones." Journal of International Economics, Vol. 4. 
International Medical Travel Journal (IMJT)., 2018. China's Hainan to boost International Medical Tourists.https://www.imtj.com/news/chinas-hainan-boost-international-medical-tourists/

Jayanthakumaran, K. 2003., "Benefit-Cost Appraisals of Export Processing Zones: A Survey of the Literature."Development Policy Review 21(1):51-65.

Kaplinsky, R., 1993. "Export Processing Zones in the Dominican Republic: Transforming Manufactures into Commodities." World Development 21(11):1851-65.

Kanbur, R., \& Zhang, X. (1999). Which regional inequality? The evolution of rural-urban and inland coastal inequality in China from 1983 to 1995. Journal of comparative economics,27(4), 686-701.

Kanbur, R., \& Zhang, X. (2005). Fifty years of regional inequality in China: A journey through central planning, reform, and openness. Review of Development Economics,9(1), 87-106. doi:10.1111/j.14679361.2005.00265.x

Li, W., \& Yang, D. T. (2005). The great leap forward: Anatomy of a central planning disaster. Journal of Political Economy,113(4), 840-877.

Lin, J., \& Liu, Z. (2000). Fiscal decentralization and economic growth in China. Economic Development and Cultural Change,49(1), 1-21.

Litwack, J., \& Qian, Y. (1998). Balanced or unbalanced development: Special economic zones as catalysts for transition. Journal of Comparative Economics,26(1), 117-141.

Lin, Justin Yifu, and Y. Wang., 2014. "China-Africa Cooperation in Structural Transformation: Ideas, Opportunities and Finances", UNU-WIDER working paper 2014/046.

Madani, D., 1999. “A Review of the Role and Impact of Export Processing Zones." World Bank Policy Research Working Paper 2238.

Monge-Gonzalez, R., et al. 2005. "Cost-Benefit Analysis of the Free Trade Zone System: The Impact of Foreign Direct Investment in Costa Rica." OAS Trade, Growth and Competitiveness Studies, Organization of American States, January.

Nee, V. (1992). Organizational dynamics of market transition: Hybrid forms, property rights, and mixed economy in China. Administrative Science Quarterly,37(1), 1-27. doi:10.2307/2393531

Nishitateno, S. (1983). China's special economic zones: Experimental units for economic reform. International and Comparative Law Quarterly,32(1), 175-185. Retrieved from http://www.jstor.org/stable/759472

Qian, Y. (2000). The process of China's market transition (1978-1998): The evolutionary, historical, and comparative perspectives. Journal of Institutional and Theoretical Economics ( JITE)/Zeitschrift $f^{\prime \prime} r$ die GesamteStaatswissenschaft,156(1), 151-171. Retrieved from http://www.jstor.org/stable/40752194

Qian, X., \& Smyth, R. (2008). Measuring regional inequality of education in China: Widening coast-inland gap or widening rural"urban gap? Journal of International Development,20(2), 132-144. doi:10.1002/jid.1396

Qui, L., Li, J., \& Sun, Q. (2003). Interregional protection of fiscal decentralization and trade liberalization.China Economic Review,14, 227-245.

Sahoo, P., Dash, R. K., \& Nataraj, G. (2010). Infrastructure development and economic growth in China. Institute of Developing Economies Discussion Paper,261.

Shankar, R. (2003). Bridging the economic divide within countries: A scorecard on the 
performance on regional policies in reducing regional income disparities. World Development,31(8), 1421-1441.

Sharma, N. (2009). Special economic zones: Socio-economic implications. Economic and Political Weekly,44(20),18-21. Retrieved from http://www.jstor.org/stable/40279007

Sun, Z. (2013). Explaining regional disparities of China's economic growth: Geography, policy and infrastructure. Berkeley, CA: University of California.

The Economist., 2015. “Special Economic Zones: Not So Special.” April 3, 2015

Telegraph., 2018.Hainan plans good news for free trade. https://www.telegraph.co.uk/news/world/china-watch/business/hainan-internationalfree-trade-zone/

Warr, P. 1989. "Export Processing Zones: The Economics of Enclave Manufacturing." The World Bank ResearchObserver 9(1):65-88.

Wan, G. (2007). Understanding regional poverty and inequality trends in China: Methodological issues and empirical findings. Review of Income and Wealth,53(1), 25-34. doi:10.1111/j.14754991.2007.00216.x

Wang, J. ( 2012). The economic impact of special economic zones: Evidence from Chinese municipalities. Journal of Development Economics,101, 133-147.

Wei, Y., \& Ye, X. (2004). Regional inequality in China: A case study of Zhejiang province. Journal of Economic and Social Geography, 95, 44-60.

Widau, G., \& Mitchell, T. (2015). China income inequality among the world's worst. Financial Times.Retrieved from https://www.ft.com/content/3c521faa-baa6-11e5-a7 cc-280dfe875e28

Xinhua News., 2017. Foreign investors with shortened FTZ negative list.http://www.xinhuanet.com/english/2017-06/22/c 136386643.htm

Xinhua News. , 2017. Xinhua Insight: China emerges as next global medical tourism hotspot. http://www.xinhuanet.com/english/2017-04/11/c 136199359.htm

Xinhua News., 2018. China Focus: China FTZs expand opening for foreign business.http://www.xinhuanet.com/english/2018-01/14/c 136894961.htm

Xinhua News., 2018. Hainan to establish new offshore duty-free shop. http://www.xinhuanet.com/english/2018-04/18/c 137120218.htm

Yeung et al., 2008. “China's Special Economic Zones at 30.” Eurasian Geography and Economics 200950 (2).

Yeung, Yue-man, J. Lee, and G. Kee., 2009. “China's Special Economic Zones at 30.” Eurasian Geography and Economics 50 (2): 222-40.

Yang, D. T. (2002). What has caused regional inequality in China? China Economic Review,13(4), 331-334.

Yitao, T., \& Meng, L. (2016). Annual report on the development of China's special economic zones. In Y. Tao \& Y. Yuan (Eds.), Annual Report on the Development of China's Special Economic Zones (pp. 3-20). Singapore: Springer.(2016)

Young, A. (2000). The Razor's edge: Distortions and incremental reform in the People's Republic of China. The Quarterly Journal of Economics,115(4), 1091-1135.

Zeng, D. Z. (Ed.). (2010). Building engines for growth and competitiveness in China: Experience with 
special economic zones and industrial clusters. Washington, D.C: World Bank Publication.

Zhang, W. W. (1999). Transforming China: Economic reform and its political implications. Hampshire: Springer.

Zhang, X., \& Fan, S. (2004). Public investment and regional inequality in rural China. Agricultural Economics,30, 89-100. doi:10.1111/j.1574-0862.2004.tb00179

Zhang, Q., \& Zou, H. F. (2012). Regional inequality in contemporary China. Annals of Economics $\mathcal{E}$ Finance,13(1). Regional Studies, Regional Science 107

Zhao, X. B. , \& Tong, S. P. ( 2000). Unequal economic development in China: spatial disparities and regional policy reconsideration, 1985-1995. Regional Studies,34(6), 549-561.

Zhou, Y. A., \& Zhang, Q. (2008). Marketization, fiscal decentralization and china economic growth [ J]. Journal of Renmin University of China,1, 008.

Zheng, Y. (2007). 10. China's de facto federalism. Federalism in Asia, 213. Hackensack, NJ: World Scientific Publishing Co.

Zheng, D., \& Kuroda, T. (2013). The role of public infrastructure in China's regional inequality and growth: A simultaneous equations approach. The Developing Economies,51(1), 79-109.

Zeng, Douglas Zhihua., 2010. Building Engines for Growth and Competitiveness in China: Experience with Special Economic Zones \& Industrial Clusters. Washington, DC: World Bank. 